\title{
Spinocerebellar ataxia type 10 Disproportionate cerebellar symptoms among at-risk subjects induced by small amounts of alcohol
}

\author{
Hélio A.G. Teive', Renato P. Munhoz', Tetsuo Ashizawa²
}

Spinocerebellar ataxia type 10 (SCA 10) is an autosomal dominant inherited ataxia caused by an expanded ATTCT pentanucleotide repeat in intron 9 of the ATXN10 gene, on chromosome 22q13.3. SCA 10 represents a rare form of SCA, described until now only in Latin America, particularly in Mexico, and Brazil ${ }^{1}$.

A 35 year old man with a three year of follow-up with genetically confirmed SCA 10 (ATTCT pentanucleotide expansion with 1500 repeats). On further questioning, the patient stated that six years prior to the present assessment, when he was physically fit, exercising regularly with no signs or symptoms of speech or gait abnormalities, an affected uncle commented that he performed on himself a predictive test for what he referred to as "the family's curse". The test consisted of drinking a regular dose of alcoholic beverage, namely, a can of beer with 350 milliliters. Habitually, the adult individuals of his family drank alcoholic beverages at the referred dose socially and sporadically with no apparent signs of gait or balance difficulties. However, certain family members including himself, presented gait and balance ataxia that was comparatively disproportionate. He also observed that all of those tested positive eventually developed the full blown clinical manifestations of SCA 10 after a variable length of time.

The effects of alcohol in the central nervous system, particularly over cerebellar function, leading to a typical dose-effect scale relating the various degrees of clinical intoxication to the blood alcohol levels ${ }^{2}$. Additionally, alcohol is a well-known cause of late cortical cerebellar degeneration of the anterior lobe ${ }^{3}$. The pharmacodynamic properties of alcohol are diverse, interfering with neuronal membranes, ion channels, enzymes, and receptors in multiple systems including acetylcholine, serotonin, glutamate, and $\gamma$-aminobutyric acid (GABA) ${ }^{4}$. The cerebellum is especially susceptible to these effects as the most important component of its circuits is the granule cell, whose excitability is controlled by the Golgi cell, a subtype of GABAergic interneuron ${ }^{4}$.

Habitually, small amounts of beverages containing alcohol are not related to cerebellar dysfunction in most people. In the United States of America moderate alcohol intake is defined as no more than two standard drinks (equivalent to $12 \mathrm{~g}$ of alcohol = approximately one can of beer) per day for men or half of that amount for women. It is estimated that an adult male (about $77 \mathrm{~kg}$ ) drinking two standard drinks on an empty stomach will have a blood alcohol content (BAC) of $0.03 \mathrm{~g} / \mathrm{dL}$ within 1 hour. The American legal BAC limit for driving is $<0.08 \mathrm{~g} / \mathrm{dL}$, thus in this regard, moderate alcohol drinkers will be considered safe drivers ${ }^{5}$.

The case presented here, of a patient with genetically confirmed SCA 10 that while on his pre symptomatic period presented significant gait ataxia and balance difficulties triggered by the ingestion of alcoholic beverages in amounts that should not induce any form of adverse neurologic symptom, illustrates the vulnerability of the cerebellum and its connections related in such cases. Another curiosity is the fact that this finding was detected by members of the family and applied as a "test" for early detection of the development of the full blown manifestations of the degenerative process.

Finally, although the description of this observation is interesting, additional study based on evidence is necessary to confirm this finding.

\section{REFERENCES}

1. Teive HAG, Munhoz RP, Arruda WO, Raskin S, Werneck LC, Ashizawa T. Spinocerebellar ataxia type 10: a review. Parkinsonism Relat Disord 2011, April 28. (Published ahead of print).

2. Vitor M, Adams RD. The effect of alcohol on the nervous system. Res Publ Assoc Res Nerv Ment Dis 1953;32:526-573.

3. Klockgether T. Acquired cerebellar ataxias and differential diagnosis. In: Brice A, Pulst S-M (Eds). Spinocerebellar degenerations: the ataxias and spastic paraplegias. Butterworth Heinemann Elsevier, Philadelphia, PA, 2007: 61-77.

4. Carta M, Mameli M, Valenzuela CF. Alcohol enhances GABAergic transmission to cerebellar granule cells via an increase in Golgi cell excitability. J Neurosci 2004;24:3746-3751.

5. Heng K, Hargarten S, Layde P, Craven A, Zhu S. Moderate alcohol intake and motor vehicle crashes: The conflict between health advantage and at-risk use. Alcohol Alcoholism 2006;41:451-454.

ATAXIA ESPINOCEREBELAR TIPO 10: SINTOMAS CEREBELARES DESPROPORCIONAIS ENTRE UM GRUPO DE SUJEITOS COM RISCO, INDUZIDOS POR PEQUENAS QUANTIDADES DE ÁLCOOL

'Movement Disorders Unit, Neurology Service, Internal Medicine Department, Hospital de Clínicas, Federal University of Paraná, Curitiba PR, Brazil; ${ }^{2}$ Department of Neurology, University of Florida, Gainesville, FL, USA.

Correspondence: Hélio A.G. Teive - Rua General Carneiro 1103/102 - 80060-150 Curitiba PR - Brasil. E-mail: hagteive@mps.com.br

Received 26 May 2011. Accepted 2 June 2011. 